J. Clin. Chem. Clin. Biochem.

Vol. 16, 1978, pp. 503-511

\title{
Estrogen and Progesterone Binding Proteins in Normal Human Myometrium and Leiomyoma Tissue ${ }^{1}$ )
}

\author{
By K. Pollow, J. Geilfuß ${ }^{2}$ ), E. Boquoi and Barbara Pollow \\ Institut für Molekularbiologie und Biochemie der Freien Universität Berlin
}

(Received May 12/June 21, 1978)

Dedicated to Prof. Dr. Dr. Ernst Schütte on the occasion of his 70 th birthday

Summary: The occurrence and characteristics of macromolecular components of normal human myometrium and leiomyoma which bind $\left[{ }^{3} \mathrm{H}\right]$ estradiol and $\left[{ }^{3} \mathrm{H}\right]$ progesterone were investigated, employing dextran coated charcoal, density gradient centrifugation and gel filtration techniques.

On sucrose density gradient centrigugation, $\left[{ }^{3} \mathrm{H}\right]$ progesterone was bound by macromolecules with sedimentation rates of about $4 \mathrm{~S}$ and $8 \mathrm{~S}$.

The major $\left[{ }^{3} \mathrm{H}\right]$ progesterone binding component had a sedimentation coefficient of about $4 \mathrm{~S}$, which contained specific and nonspecific binding sites.

Sedimentation patterns as well as elution profiles from agarose gel revealed a striking similarity between biochemical properties of the progesterone receptors from normal myometrium and leiomyomas of the same organ.

Both progesterone and estradiol receptor change in concentration during the normal menstrual cycle. During the early proliferative phase the number of estradiol receptor binding sites was highest; after ovulation, a rapid decrease of estradiol receptor level was seen. On the other hand, using $\left[{ }^{3} \mathrm{H}\right]$ progesterone as the ligand, the highest receptor concentration was found at midcycle.

The leiomyoma steroid hormone receptor levels were compared with those in normal myometrium. Whereas leiomyoma exhibited higher estradiol binding capacity, the concentration of progesterone receptors was low in fibroid tumors.

\section{Östrogen- und Progesteron-Rezeptören in normalem Humän-Myometrium und Myomen}

Zusammenfassung: Das Vorkommen makromolekularer Bindungskomponenten für [ $\left.{ }^{3} \mathrm{H}\right]$ östradiol und [ $\left.{ }^{3} \mathrm{H}\right]$ Progesteron in normalem Human-Myometrium und Myomen wurde untersucht und die Charakterisierung mit Hilfe der Dichtegradienten-Zentrifugationstechnik und Gelfiltration vorgenommen. Die Quantifizierung erfolgte mit einer modifizierten Dextran-Aktivkohle-Technik.

Im Saccharöse-Dichtegrạdienten sẻdimentierte im KCl-freien Medium der $\left[{ }^{3} \mathrm{H}\right]$ Progesteron-Rezeptor im $4 \mathrm{~S}$ - und $8 \mathrm{~S}$-Bereich. Die Hauptbindungskomponente war im $4 \mathrm{~S}$-Bereich lokalisiert, die neben spezifischen Bindungsbezirken unspezifische Bindungsaktivität aufwies.

Die Sedimentatịnsprofịle șowiè die Elutionsprofilè nach Agarose-Gelfiltration demonstrieren eine auffällige Ähnlichkeit zwischen den biochemischen Eigenschaften der Progesteron-Rezeptoren aus normalem Myometrium und Myomen des gleichen Uterus.

In normalem Gewebe variieren die Progesteron- sowie östradiol-Rezeptorkonzentrationen in der Cytoplasmafraktion. Die höchsten Ö́stradiol-Rezeptorbindungsaktivitäten wurden während der frühen Proliferationsphase beobachtet; nach Ovilation kommt es zu einem rapiden Abfall der Östradiol-Rezeptorkonzentration. Die höchsten ProgesteronRezeptorkonzentrationen zeichneten sich ab in der Mitte des Menstruationszyklus zum Zeitpunkt der Ovulation. Myome waren charakterisiert durch hohe Östrạdiol-Bindungṣkapazität und eine niedrigere Progesteron-Rezeptorkonzentration.

1) This work was supported by the Deutsche Forschungsgemeinschaft.

${ }^{2}$ ) This work will be a part of a Thesis by J. G. 


\section{Introduction}

The uterus, the target organ for ovarial steroid hormones, has a property characteristic of target organs, i. e., the accumulation of steroid hormones against a concentration gradient. Specific high affinity cytoplasmic receptor proteins for steroid hormones, whose existence was first demonstrated by Jensen et al. (1), are responsible for this phenomenon. These receptor proteins, of which there is one specific type for each steroid hormone, are essential components in the chain of action of steroid hormones in the target cell. After the steroid hormone has entered the target cell from the blood, it binds to the appropriate receptor molecule to form a hormone-receptor complex, which translocates to the nucleus after activation. In the nucleus, the site of the genetic apparatus, the hormone receptor complex binds to the chromatin. This interaction leads to activation at the transcription level, followed by an increase in protein synthesis. Although a large number of the individual processes in this sequence are still unclear, it is probable that some of them are the cause of growth and/or differentiation of the uterus under the influence of steroid hormones.

Studies on the specific cytoplasmic receptor proteins binding estradiol and progesterone in human myometrium and endometrium have shown that the concentrations of these steroid hormone receptors change during the course of the menstrual cycle (2-10). Practical clinical experience has also shown that the growth of leiomyomas, benign neoplasias of the muscle layer of the uterus, can be affected by changes in the hormone status during the menstrual cycle and during pregnancy. The question is, why leiomyomas escape the growth inhibition exerted by the surrounding hormonal milieu, and develop, so to speak, their own growth control. Comparison of the steroid hormone receptors in normal myometrium and leiomyomas from the same uterus may help to answer this question. In this connection, not only the quantitative analysis of the estrogen and progesterone binding receptor molecules is of interest, but also the biochemical characterization of the two receptors in normal and neoplastic tissues.

\section{Materials and Methods}

Steroids

$\left[1,2-{ }^{3} \mathrm{H}\right]$ Progesterone (spec. activity $1.96 \mathrm{PBq} / \mathrm{mol}=$ $53 \mathrm{Ci} / \mathrm{mmol}$ ) and $\left[6,7-{ }^{3} \mathrm{H}\right]$ estradiol- $17 \beta$ (spec. activity $1.48 \mathrm{PBq} / \mathrm{mol}=40 \mathrm{Ci} / \mathrm{mmol}$ ) were purchased from the 'Radiochemical Centre (Amersham, England). All radioactive steroids were purified by thin-layer chromatography before use.

Unlabelled steroids were a gift from Schering AG (Berlin, Germany).

\section{Tissue}

Uterine tissue was obtained from normal fertile or postmenopausal women, who underwent hysterectomy because of myomata uteri. Immediately after hysterectomy the uterus was placed on ice, myometrium and endometrium were separated from one another, and portions of each tissue were removed for microscopic study. The interval between hysterectomy and the start of the cytosol preparation was usually less than $30 \mathrm{~min}$. The menstrual age of the myometrium was based on a 28-day cycle by rating histological sections of normal endometrium according to the scheme of Noyes et al. (11).

\section{Preparation of subcellular fractions}

Tissue was processed at $4{ }^{\circ} \mathrm{C}$. Fresh tissue samples were weighed, washed in ice cold buffer (containing $50 \mathrm{mmol} / \mathrm{l}$ tris $/ \mathrm{HCl}$, pH 7.0, $1.25 \mathrm{mmol} / 1 \mathrm{EDTA}, 12 \mathrm{mmol} / 1$ mercaptoethanol, $200 \mathrm{ml} / 1$ glycerol), and gently homogenized in a 4-fold volume $(w / v)$ of the same buffer. Homogenization was performed with an Ultra Turrax for 5 pulses (each $20 \mathrm{~s}$ ). This homogenization was followed by homogenization with a glass homogenizer fitted with a teflon pestle ( 5 strokes). The homogenate was filtered through 4 layers of cheese-cloth. To obtain the nuclear fraction, the filtrate was centrifuged at $850 \mathrm{~g}$ for $15 \mathrm{~min}$, and the nuclear pellet washed twice in buffer $A(10 \mathrm{mmol} / \mathrm{l}$ tris/ $\mathrm{HCl}, 0.1 \mathrm{~mol} / 1 \mathrm{NaCl}, 5 \mathrm{mmol} / 1 \mathrm{KCl}, 3 \mathrm{mmol} / 1 \mathrm{MgCl}_{2}, 1.5 \mathrm{mmol} / 1$ $\mathrm{CaCl}_{2}, 200 \mathrm{ml} / 1$ gly cerol, $\mathrm{pH} 7.0$ ) by dispersing with a Dounce homogenizer and centrifuged twice at $850 \mathrm{~g}$ for $15 \mathrm{~min}$. The nuclear pellet was resuspended in buffer $A$ containing $2.4 \mathrm{~mol} / 1$ sucrose, layered on a cushion of $2.4 \mathrm{~mol} / 1$ sucrose buffer $A$ and centrifuged at $60,000 \mathrm{~g}$ for $60 \mathrm{~min}$ at $4^{\circ} \mathrm{C}$. The resulting pellet was designated the "purified nuclei".

The $850 \mathrm{~g}$ supernatant was centrifuged for $30 \mathrm{~min}$ at $105,000 \mathrm{~g}$ to obtain a clear cy tosol containing only the fully soluble proteins.

Serum was obtained by low speed centrifugation of the blood samples of pregnant women and was stored at $-70^{\circ} \mathrm{C}$.

Sucrose density gradient centrifugation

Samples (4.6 mg protein per $\mathrm{ml}$ cy tosol) for density gradient cen trifugation ( 5 to $20 \%$ linear sucrose gradient in tris-EDTAmercaptoethanol-glycerol buffer) with or without $\mathrm{KCl}$ were reacted for $10 \mathrm{~h}$ at $4{ }^{\circ} \mathrm{C}$ with $2 \mathrm{nmol} / 1\left[{ }^{3} \mathrm{H}\right]$ progesterone without any competitor. In a second set of tubes. a 100-fold excess of unlabelled progesterone or cortisol was added to the radioactive steroid. Incubations were performed for $16 \mathrm{~h}$ at $4{ }^{\circ} \mathrm{C}$. Thereafter $0.2 \mathrm{ml}$ aliquots of the samples were centrifuged for $16 \mathrm{~h}$ at $234,000 \mathrm{~g}$ (rotor $\mathrm{SW} 50.1$, Beckman Instruments).

Bovine serum albumin was run simultaneously as the reference protein in the estimation of sedimentation coefficients. Fractions were collected from the top of the gradient by means of the Isco-piercing unit and drop counter. Radioactivity was determined in $0.1 \mathrm{ml}$ aliquots of undiluted fractions. Quenching of radioactivity by sucrose did not vary significantly.

\section{Agarose gel filtration}

Bio Gel A-0.5 m (200-400 mesh, Bio-Rad Laboratories, München, Germany) was packed in columns $(1.5 \mathrm{~cm} \mathrm{i.} \mathrm{d.)} \mathrm{to} \mathrm{a}$ height of $100 \mathrm{~cm}$ and washed with the eluting buffer solution (tris-EDTA-mercaptoethanol-glycerol buffer). The gel exclusion characteristics of the column were measured with standard proteins. Samples (15.8 mg protein per ml cy tosol) were applied to the column in $2 \mathrm{ml}$ volumes together with Chlorophenol Red and Dextran Blue to serve as indicators. Dextran Blue was eluted in the void volume while the red dye was eluted with free $\left[{ }^{3} \mathrm{H}\right]$ steroid. Elution was carried out at a flow rate of $8.5 \mathrm{ml} / \mathrm{h}$. Then $1.5 \mathrm{ml}$ fractions were collected and aliquots were counted for radioactivity.

Measurement of progesterone binding sites in myometrial cy tosol by equilibrium dialysis

Cytosols were diluted with tris-EDTA-mercaptoethanôl-glycerol buffer to a final protein concentration of $1 \mathrm{~g} / 1$. The equilibrium dialysis was performed according to the method described in detail by Davies (12). A dialysis bag containing $1 \mathrm{ml}$ of cy tosol was introduced into $5 \mathrm{ml}$ of homogenization buffer containing increasing concentrations of $\left[{ }^{3} \mathrm{H}\right]$ progesterone $(0.2-20 \mathrm{nmol} / \mathrm{l})$ and a constant amount of unlabelled cortisol, 100-fold molar 
excess over the highest $\left[{ }^{3} \mathrm{H}\right]$ steroid level. Cortisol was added to eliminate binding by contaminating serum corticosteroidbinding globulin. The diluted cy tosols were incubated at $4{ }^{\circ} \mathrm{C}$ for $16 \mathrm{~h}$ with shaking. The deviation of the number of binding sites as well as the association constant $\left(\mathrm{K}_{\mathrm{a}}\right)$ from the multiple dialysis were based on linearization of the data as described by Scatchard (13).

\section{Determination of estradiol binding}

The diluted cytosols $(1 \mathrm{~g} / \mathrm{l})$ were incubated at $4{ }^{\circ} \mathrm{C}$ for $16 \mathrm{~h}$ with $\left[{ }^{3} \mathrm{H}\right]$ estradiol over a 30 -fold concentration range $(0.5$ to $15 \mathrm{nmol} / \mathrm{l})$. Tubes containing $1 \mu \mathrm{mol} / 1$ unlabelled estradiol were used to correct for nonspecific binding. Binding was then measured using the charcoal adsorption technique: The pellet obtained from the centrifugation $(2 \mathrm{~min}$ at $10,000 \mathrm{~g}$ ) of $0.4 \mathrm{ml}$ of $2.5 \mathrm{~g} / \mathrm{l}$ charcoal plus $0.25 \mathrm{~g} / \mathrm{l}$ dextran in $50 \mathrm{mmol} / 1 \mathrm{tris} / \mathrm{HCl}$ buffer (pH 7.0) was mixed with the cy tosol; after 20 min at $4^{\circ} \mathrm{C}$, the dextran-coated charcoal was removed by centrifugation for $10 \mathrm{~min}$ at $10,000 \mathrm{~g}$. The bound radioactivity of the samples was counted for radioactivity.

The association constant $\left(\mathrm{K}_{\mathrm{a}}\right)$ and the concentration of binding sites were calculated according to Scatchard.

A ssay of nuclear binding

of $\left[{ }^{3} \mathrm{H}\right]$ estradiol and $\left[{ }^{3} \mathrm{H}\right] p r o g e s t e r o n e$

Myometrial tissue slices were incubated in Eagle's medium at $37^{\circ} \mathrm{C}$ for $60 \mathrm{~min}$ with $5 \mathrm{nmol} / 1\left[{ }^{3} \mathrm{H}\right]$ progesterone or $\left[{ }^{3} \mathrm{H}\right]$ estradiol. Purified nuclear fractions were prepared as described above and extracted with $0.4 \mathrm{~mol} / 1 \mathrm{KCl}, 10 \mathrm{mmol} / 1 \mathrm{tris} / \mathrm{HCl}$ (pH 7.0), $1.5 \mathrm{mmol} / 1$ EDTA buffer, at $4^{\circ} \mathrm{C}$ for $30 \mathrm{~min}$. Aliquots of $0.4 \mathrm{~mol} / 1 \mathrm{KCl}$ extracts $(0.2 \mathrm{ml})$ were layered onto $50-200 \mathrm{~g} / 1$ sucrose gradients, containing $0.3 \mathrm{~mol} / 1 \mathrm{KCl}$ as described above.

In order to determine the transfer of $\left[{ }^{3} \mathrm{H}\right]$ estradiol or $\left[{ }^{3} \mathrm{H}\right]$ progesterone from cytosol to nucleus, tissue slices from early proliferative and early secretory myometrium as well as leiomyoma were incubated in Eagle's medium for $10 \mathrm{~min}$ at $4^{\circ} \mathrm{C}$, then rinsed and transferred to fresh Eagle's medium and incubated for various periods as indicated at $37^{\circ} \mathrm{C}$. After incubation the tissue was homogenized and fractionated as described under "Preparation of subcellular fractions". The nuclear pellet was purified by passing through $2.4 \mathrm{~mol} / \mathrm{l}$ sucrose. The cy toplasmic fraction and purified nuclei were then extracted with chloroform/ethanol $(3 \mathrm{ml}+1 \mathrm{ml})$. The ordinate is expressed as counts per min per $1.0 \mathrm{~g}$ of tissue.

\section{Protein assay}

Protein was measured using the method of Lowry et al. (14) with bovine serum albumin as standard.

\section{Results}

The kinetics of $\left[{ }^{3} \mathrm{H}\right]$ progesterone binding to specific receptor molecules of human normal myometrium and leiomyoma cytosol is demonstrated in figure 1 . It is evident that after $10 \mathrm{~h}$ at $4{ }^{\circ} \mathrm{C}$, the amount of bound radioactivity remained constant up to $100 \mathrm{~h}$ of incubation. In all further experiments an incubation time of at least $16 \mathrm{~h}$ was employed.

Figure 2 illustrates the rates of dissociation of $\left[{ }^{3} \mathrm{H}\right]$ progesterone from the cytosol receptor binding site from myometrium and leiomyoma. The two progesterone receptor complexes have similar dissociation rates.

Sucrose density gradient ( 50 to $200 \mathrm{~g} / \mathrm{l}$ ) centrifugation of normal myometrium and leiomyoma cytosol incubated with $\left[{ }^{3} \mathrm{H}\right]$ progesterone in the presence of

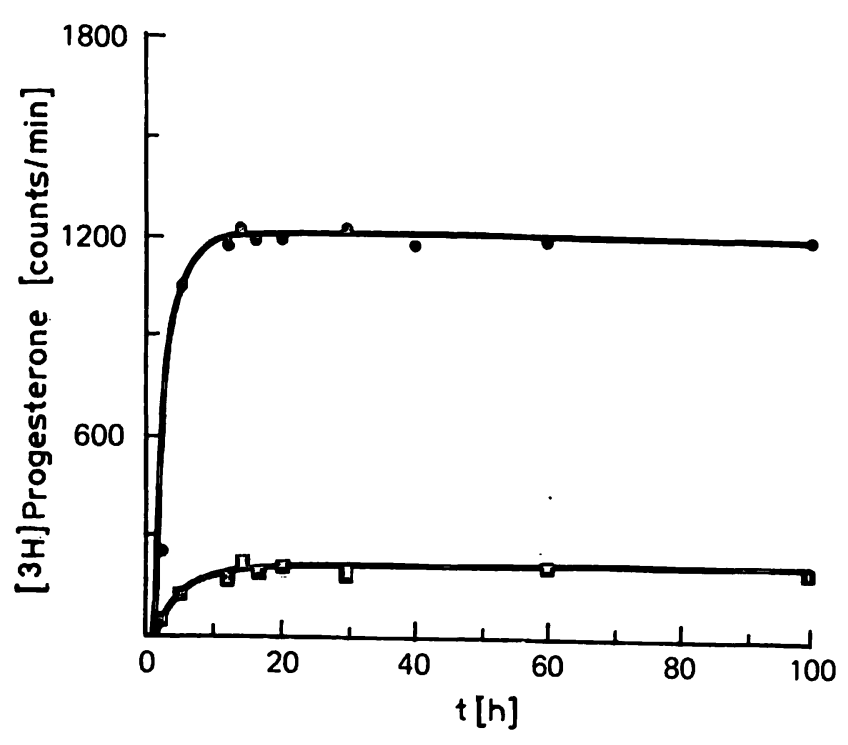

Fig. 1. Kinetics of $\left[^{3} \mathrm{H}\right]$ progesterone binding to cytosol components in human myometrium in the early secretory phase (closed circles), and in leiomyoma (closed squares).

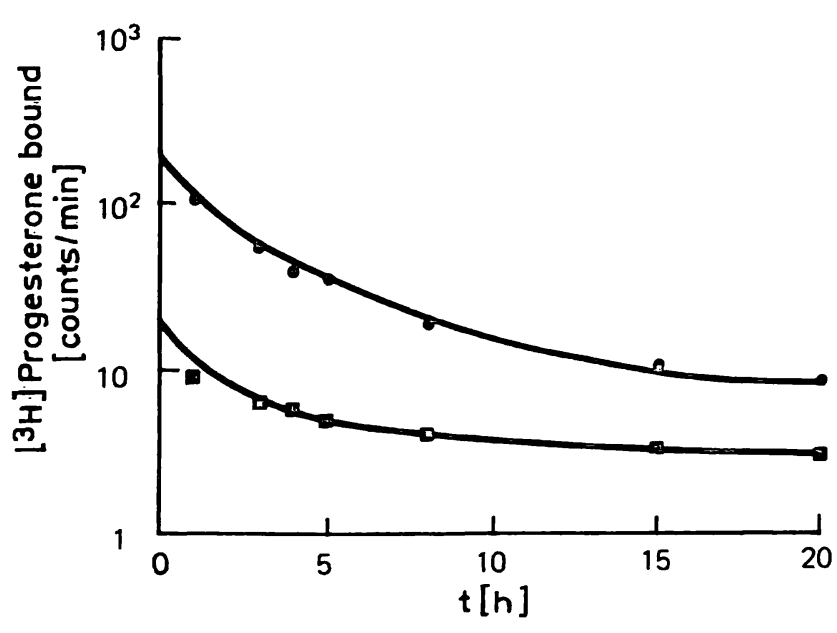

Fig. 2. Dissociation rate of cytoplasmic progesterone receptor complexes of early secretory myometrium (closed circles) and leiomyoma (closed squares).

Cytosol was incubated with $2 \mathrm{nmol} / \mathrm{l}$ radioactive ligand for $16 \mathrm{~h}$ at $4^{\circ} \mathrm{C}$. Unlabelled progesterone $(100 \mathrm{nmol} / \mathrm{l})$ was added and bound radioactivity was measured at different times by the dextran coated charcoal technique.

$0.3 \mathrm{~mol} / \mathrm{K} \mathrm{KCl}$ produced a marked radioactivity peak in the $4 \mathrm{~S}$ region (fig. 3).

Unlabelled cortisol partially displaced $\left[{ }^{3} \mathrm{H}\right]$ progesterone from this binding component, while unlabelled progesterone was capable of almost complete displacement of $\left[{ }^{3} \mathrm{H}\right]$ progesterone from the $4 \mathrm{~S}$ binding component. In the absence of $\mathrm{KCl}$, two peaks of radioactivity with sedimentation rates of about $8 \mathrm{~S}$ and $4 \mathrm{~S}$ were noted on density gradient centrifugation. The sedimentation profiles revealed a striking similarity between receptors of normal myometrium and leiomy oma, but the amounts of $\left[{ }^{3} \mathrm{H}\right]$ progesterone in the $4 \mathrm{~S}$ and $8 \mathrm{~S}$ regions were reduced in leiomyoma samples. As presented in this 

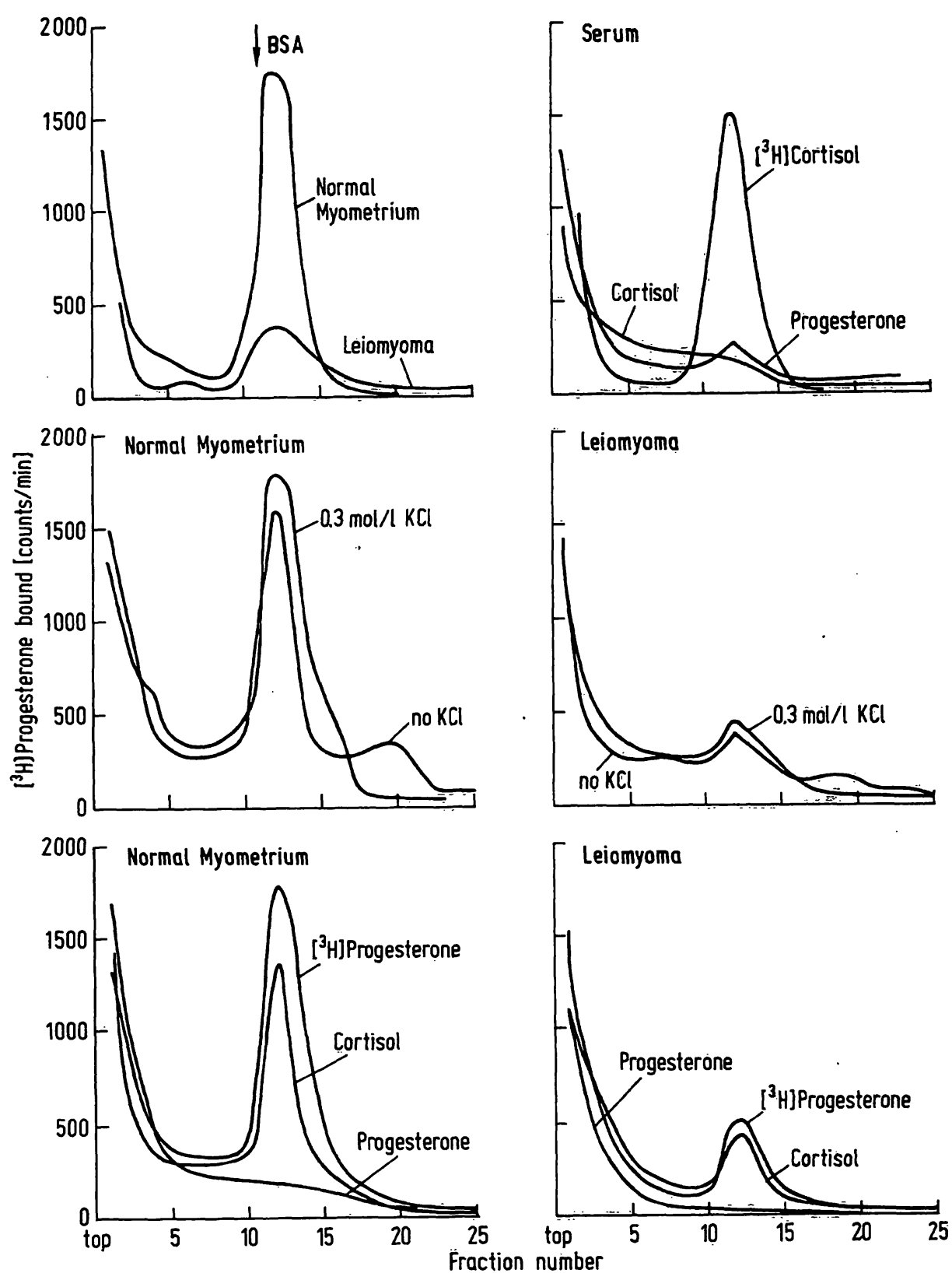

Fig. 3. Sedimentation properties of progesterone binding proteins at different KCl-concentrations in human myometrium, leiomyo$\mathrm{ma}$, and pregnant serum.

The samples were incubated with $\left.2 \mathrm{nmol} / 1 \mathrm{I}^{3} \mathrm{H}\right]$ progesterone alone or in the presence of a 100 -fold excess of unlabelled steroids.

figure the $4 \mathrm{~S}$ component is not distinguishable from the corticosteroid binding globulin (CBG) of human pregnant serum.

The elution patterns shown in figure 4 were obtained when progesterone-labelled cytosols of normal myometrium and leiomyoma were chromatographed on agarose gel in the presence of $0.3 \mathrm{~mol} / \mathrm{K} \mathrm{KCl}$. The major progesterone binding activity chromatographed as a single peak (fraction number 60 ) close behind $\mathrm{CBG}$; free $\left[{ }^{3} \mathrm{H}\right]$ progesterone was eluted within the elution volume of fraction 80 to 100 . The radioactive peak of fraction 60 was mostly eliminated by the addition of unlabelled progesterone during the incubation of cytosol with $\left[{ }^{3} \mathrm{H}\right]$ progesterone. The elution profiles obtained with normal human myometrium were similar to those of leiomyoma, except that binding of $\left[{ }^{3} \mathrm{H}\right]$ progesterone was very low in the main peak of radioactivity (fraction number 60).

Concentration of the cy toplasmic progesterone binding components during the menstrual cycle and in leiomyoma

The progesterone receptor levels found at various times in the menstrual cycle are shown in figure 5. Dating of the myometrial tissue was performed by staging endometrial samples of the uterus histologically with 


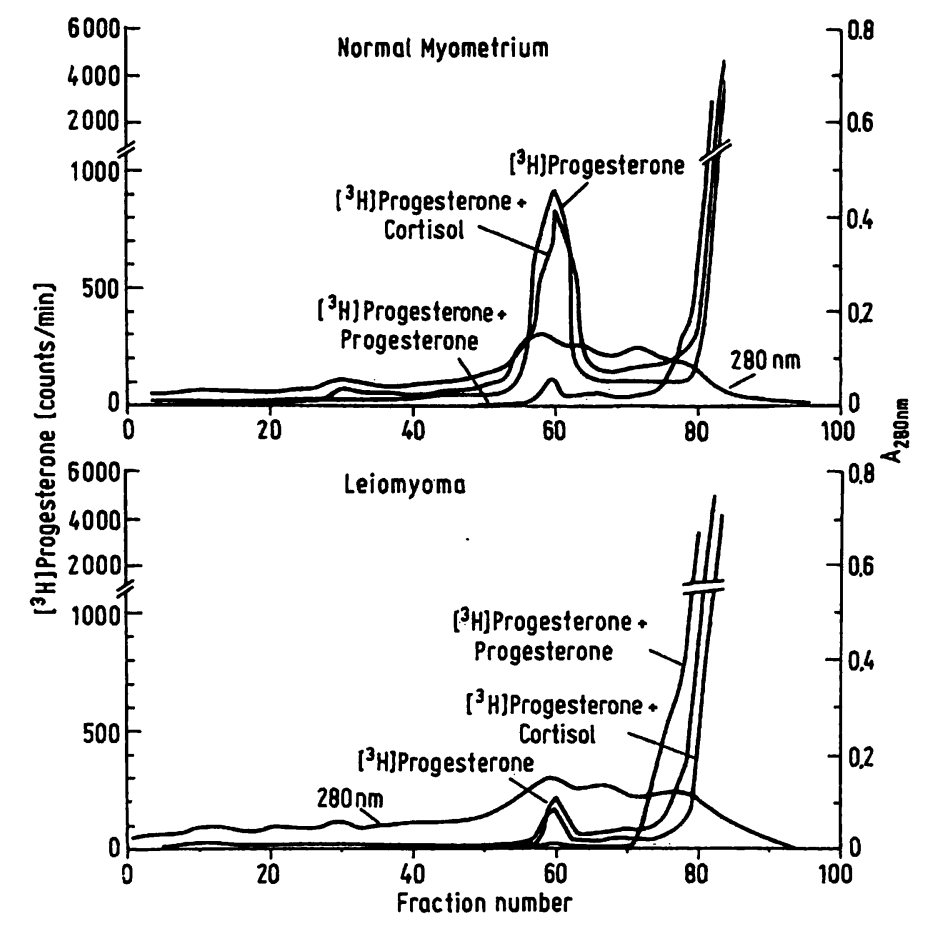

Fig. 4. Chromatographic patterns obtained from agarose gel filtration of cytoplasmic $\left[{ }^{3} \mathrm{H}\right]$ progesterone binding components of normal myometrium and leiomyoma obtained from the same tumor-bearing uterus.

Cytosol samples were incubated with $2 \mathrm{nmol} / 1\left[{ }^{3} \mathrm{H}\right.$ )progesterone for $10 \mathrm{~h}$ at $4^{\circ} \mathrm{C}$ with or without 100 -fold excess-unlabelled progesterone or cortisol relative to $\left[{ }^{3} \mathrm{H}\right]$ progesterone.

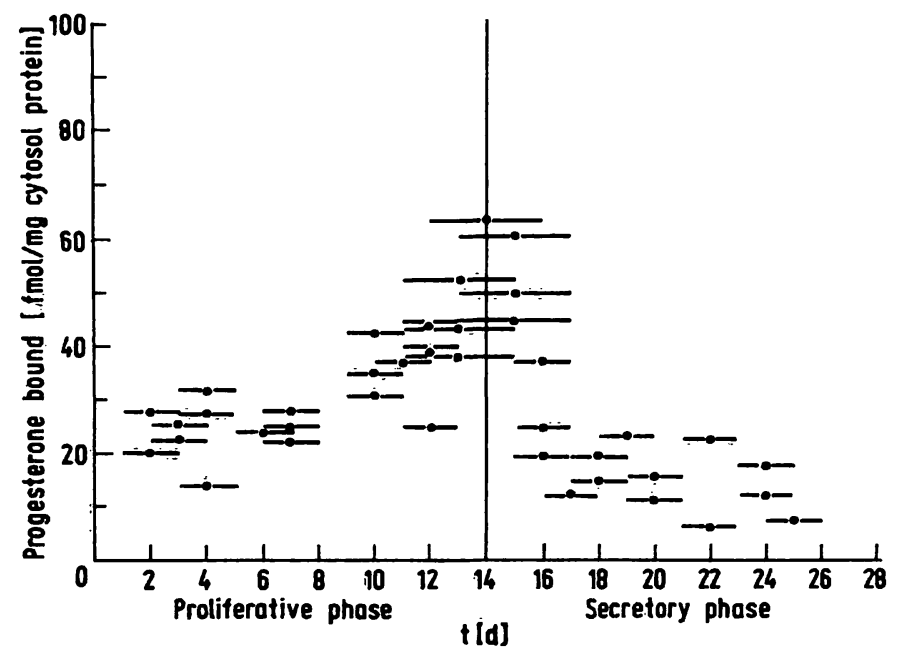

Fig. 5. Concentration of specific progesterone binding sites of normal human myometrial cytosol in relation to the day of the menstrual cycle.

For the determination of the progesterone receptor concentration, myometrial cytosol was incubated with increasing amounts of $\left[{ }^{3} \mathrm{H}\right.$ ]progesterone in the presence of an excess of unlabelled cortisol.

respect to the phase of the menstrual cycle. In general, the proliferative specimens contain significantly higher concentrations of progesterone receptor than the secretory samples. During the proliferative phase the progesterone receptor level increased toward the 14th day of the menstrual cycle, reached its highest value around the time of ovulation and declined sharply during the secretory phase.

In figure 6 the specific progesterone binding capacity of cytosol obtained from normal myometrium is plotted against the age of the women. The highest binding site concentrations were found in tissue samples of normal fertile women; in postmenopausal uteri the specific binding capacity was low.

The cytosols of 16 leiomyomas were examined for the presence of progesterone-specific binding (fig. 7). In all tumor samples progesterone binding activity was detectable, but the leiomyomas had significantly lower binding activity than did normal human myometrium obtained from normal fertile or postmenopausal women.

A comparison of the $\mathrm{K}_{\mathrm{d}}$-values of the progesterone receptor complex in each stage of the menstrual cycle, in postmenopausal tissue or in leiomyoma indicated that there was no statistically significant difference in their dissociation constants (normal myometrium: $9.8 \mp 0.3 \cdot 10^{-9} \mathrm{~mol} / 1$; leiomyoma: $11 \mp 0.9$ $\left.10^{-9} \mathrm{~mol} / \mathrm{l}\right)$.

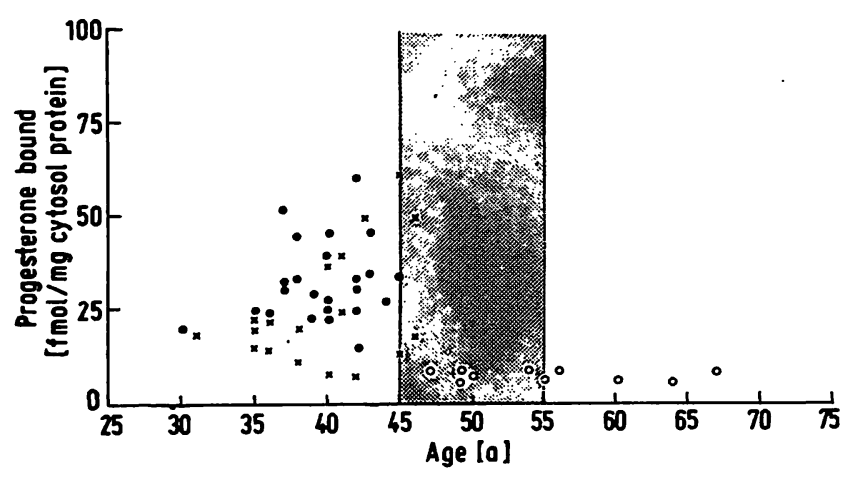

Fig. 6. Progesterone receptor concentration in human myometrial cytosol in relation to menopausal status. - = proliferative myometrium; $x$ = secretory myometrium $0=$ postmenopausal myometrium (atrophic endometrium)

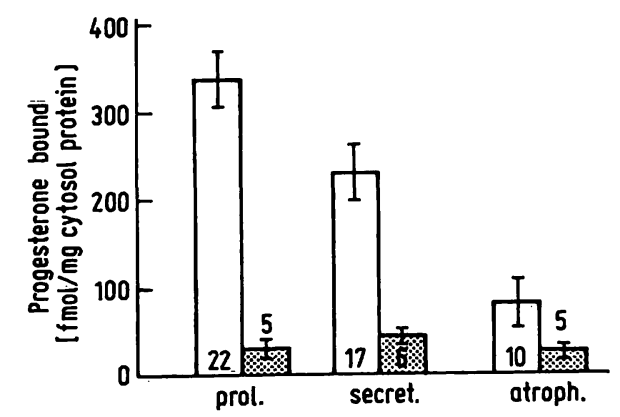

Fig. 7. Comparison of the binding capacity of cytosol of normal myometrium and leiomyoma for progesterone in pre- and postmenopausal women (prol. = proliferative phase; secret. = secretory phase; atroph. $=$ atrophic endometrium). Numbers in bars represent the number of patients studied. 


\section{Concentration}

of the specific estradiol binding sites

during the menstrual cycle and in leiomyom a

The level of unoccupied specific cytoplasmic estradiol receptor reached a maximum early in the first half of the cycle and steadily declined thereafter, to its lowest value late in the secretory phase (fig. 8).

The influence of the age of the patient on the cytoplasmic estradiol receptor content in normal myometrium is shown in figure 9. Premenopausal patients were those regularly menstruating; postmenopausal ones had their last menstrual period at least 1 year before. With regard to the mean receptor concentrations, the estradiol receptor levels were significantly lower in pre- than in post-menopausal women, whereas the reverse was true for the progesterone receptor binding activity (see fig. 6). The cytosols of 32 leiomyomas were examined for the presence of estradiol-specific

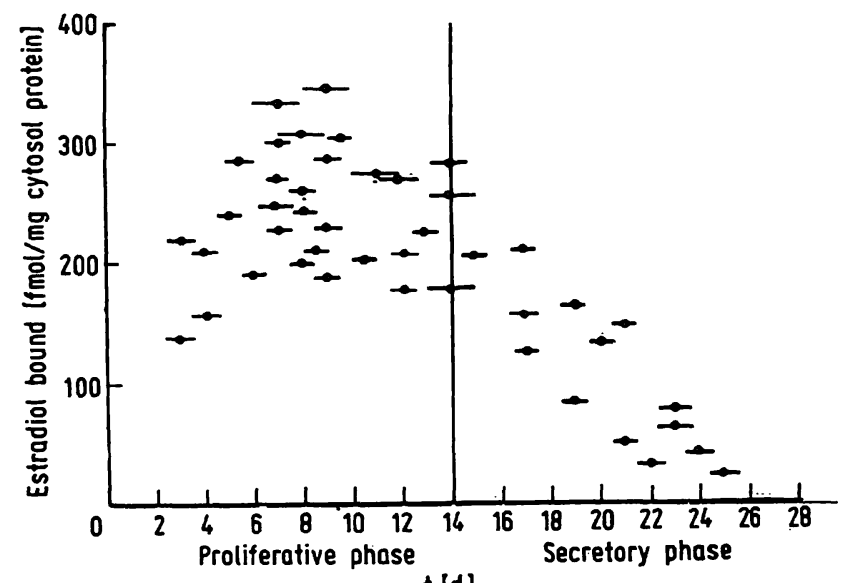

$+[d]$

Fig. 8. Specific $\left[{ }^{3} \mathrm{H}\right]$ estradiol binding concentration of myometrial cytosol in relation to the day of the menstrual cycle.

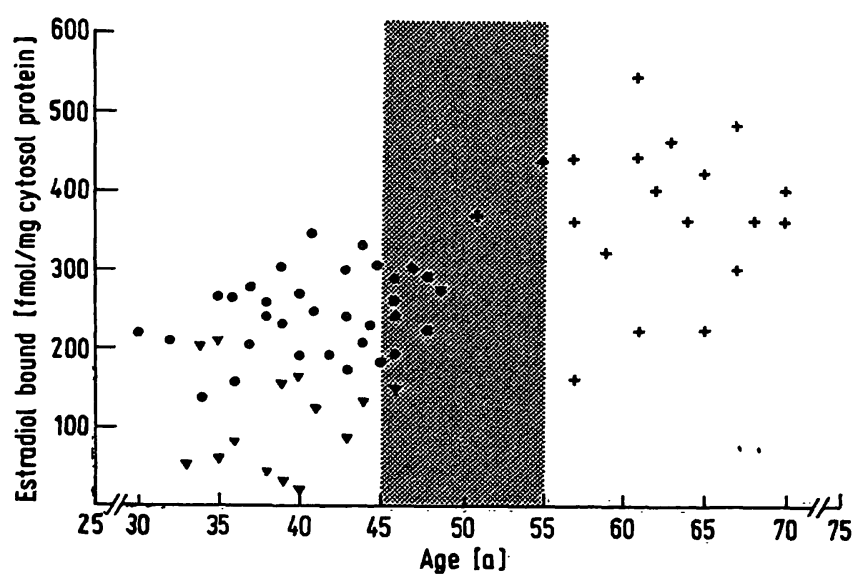

Fig. 9. Estradiol receptor concentration in human myometrial cytosol in relation to menopausal status.

- = proliferative myometrium; $\nabla=$ secretory .myometrium; $x$ = postmenopausal myometrium (atrophic endometrium).

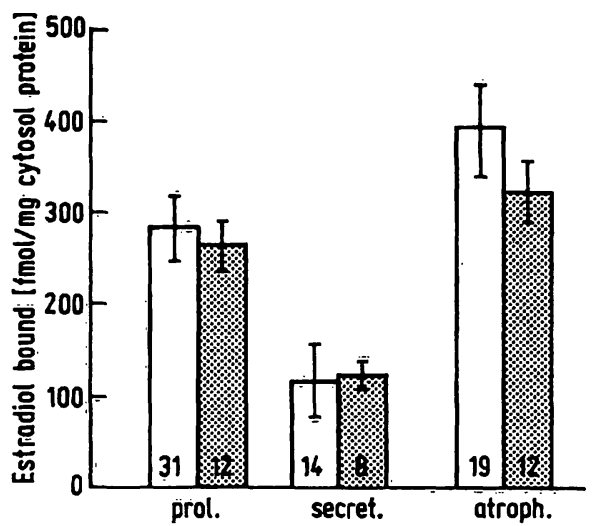

Fig. 10. Comparison of the binding capacity of cytosol of normal myometrium and leiomyoma for estradiol in preand post-menopausal women.

prol. $=$ proliferative phase $;$ secret.$=$ secretory phase; atroph. $=$ atrophic endometrium

Numbers in bars represent the number of patients studied.

binding (fig. 10). The concentration of estradiol receptors wās not significantly different in leiomyomas and normal myometrium. There was no evident correlation between the association constant and the histological type of the tissue (normal myometrium: $6.8 \mp 0.3$. $10^{9} \mathrm{l} / \mathrm{mol}$; leiomyoma: $8.8 \mp 0.2 \cdot 10^{9} \mathrm{l} / \mathrm{mol}$ ).

\section{Nuclear estradiol and progesterone receptors}

The variation of binding profiles as a function of the menstrual cycle is shown in relation to nuclear $\left[{ }^{3} \mathrm{H}\right]$ estradiol- and $\left[{ }^{3} \mathrm{H}\right]$ progesterone-binding profiles in leiomyoma (fig. 11). Under high resolution conditions, no significant difference in the sedimentation patterns of nuclear $\left[{ }^{3} \mathrm{H}\right]$ estradiol and $\left[{ }^{3} \mathrm{H}\right]$ progesterone binding sites from proliferative myometrium and leiomyoma could be found. These patterns were characterized by high $\left[{ }^{3} \mathrm{H}\right]$ estradiol and low $\left[{ }^{3} \mathrm{H}\right]$ progesterone binding activity. In the nuclear myometrial extract of the secretory phase, the converse was the case.

Myometrial tissue slices were pre-incubated for $10 \mathrm{~min}$ at $4{ }^{\circ} \mathrm{C}$ to allow passive diffusion of the $\left[{ }^{3} \mathrm{H}\right]$ labelled steroids into the cell, and the tissue was then incubated for various periods of time as indicated in figure 11 . The relative $\left[{ }^{3} \mathrm{H}\right]$ contents of the cytoplassm and purified nuclei were then determined. Initially, for both $\left[{ }^{3} \mathrm{H}\right]$ estradiol and $\left[{ }^{3} \mathrm{H}\right]$ progesterone, the tritium was located almost completely in the cytosol fraction, while relatively little was present in the purified nuclear pellet. Upon continued incubation, there was an increase in nuclear $\left[{ }^{3} \mathrm{H}\right]$ binding and progressive decrease in $\left[^{3} \mathrm{H}\right]$ binding in cytoplasmic binding components, suggesting that the hormone was sequentially transferred to the nucleus. The transfer mechanism in leiomyoma is comparable to that in the normal proliferative phase myometrium. 


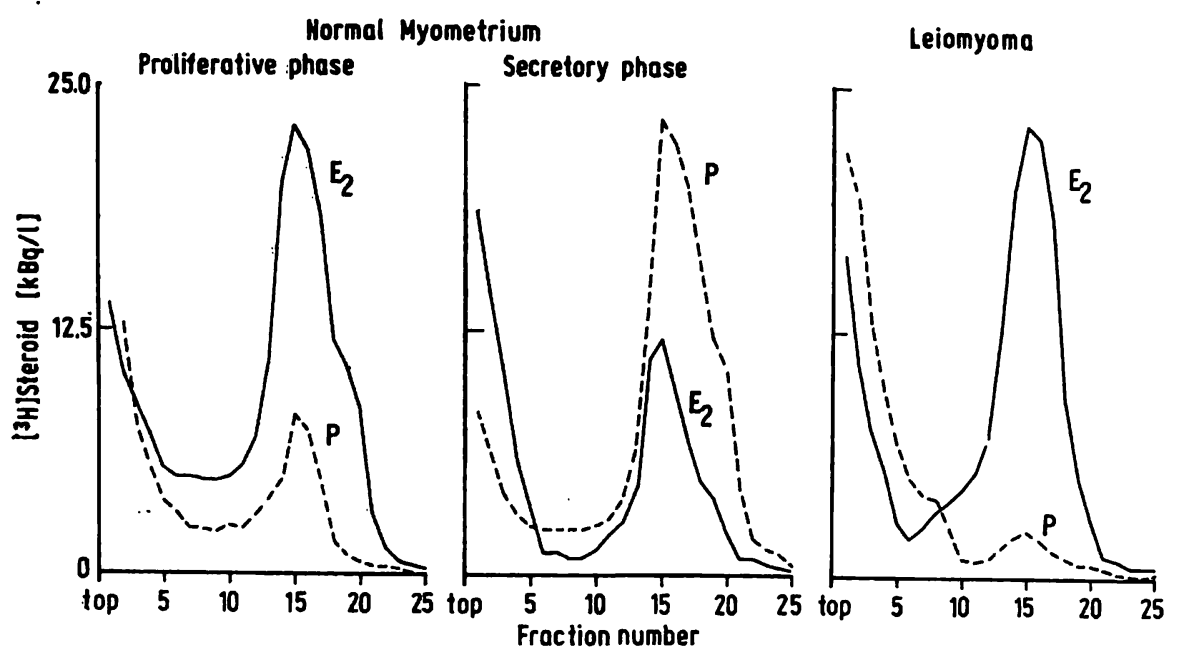

Fig. 11. $\left[{ }^{3} \mathrm{H}\right]$ estradiol (closed line) and $\left[{ }^{3} \mathrm{H}\right]$ progesterone (dotted line) binding components of myometrial nuclei demonstrated by sucrose density gradient centrifugation.

Nuclei were prepared from early proliferative and early secretory phase of normal human myometrium and from leiomyoma of postmenopausal women as described under "Materials and Methods".

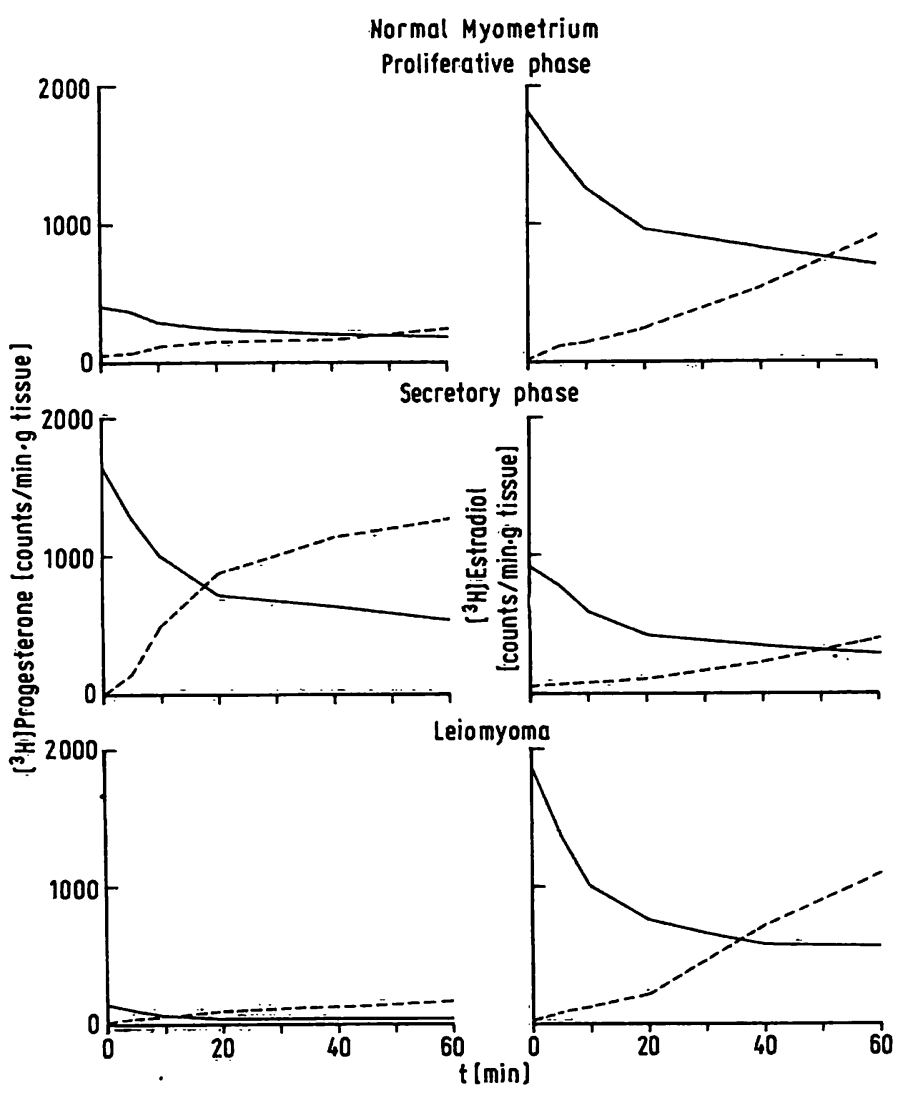

Fig. 12. Transfer of $\left[{ }^{3} \mathrm{H}\right]$ estradiol and $\left[{ }^{3} \mathrm{H}\right]$ progesterone from cytosol to nucleus.

Tissue slices from early proliferative ( 3 cases) and early secretory ( 5 cases) myometrium and from leiomyoma (4 cases) were incubated in Eagle's medium for $10 \mathrm{~min}$ at $4^{\circ} \mathrm{C}$, then rinsed and transferred to fresh Eagle's medium and incubated for various periods as indicated. After.incubation the tissue was homogenized and fractionated as described under "Materials and Methods". Cytoplasmic fraction $(-)$ and purified nuclei $(-=-)$ were then extracted with chloroform/ethanol (volumes, $3+1$ ).

\section{Discussion}

The results of the present studies demonstrate the existence of high-affinity, low-capacity binding components for estradiol and progesterone in the cytoplasmic fractions of normal myometrium and leiomyomas. These specific hormone-binding protein components have the properties of receptors (sedimentation in density gradients, competitive binding studies, elution profile after agarose gel filtration, high affinity binding). These observations confirm the studies of others (15-27).

Comparison of the biochemical properties of the cytoplasmic progesterone binding receptor molecules from normal and neoplastic myometrium (for the estradiol receptor, see Pollow et al., l. c. (28)) shows that there are no differences between the receptors from these two tissues with respect to their affinity for progesterone, their sedimentation properties in sucrose density gradient, or their elution profile after agarose gel filtration. This indicates that the neoplastic tissue contains a progesterone receptor which is similar or identical to the one found in normal human myometrium. Quantitative differences between the two types of tissue were observed with respect to binding of ovarial steroid hormones. In normal human myometrium, the concentration of progesterone binding receptor sites varies during the menstrual cycle. Cycle-dependent variations in the concentration of the receptor proteins are particularly interesting, because the hormone receptors directly influence the control of the genetic apparatus. The highest concentrations of progesterone receptors were observed in mid-cycle. This is an agreement with the results of Illingworth et al. (26), and Kontula (21). 
Examination of the estradiol receptors in the myometrium during the fertility period showed that the highest cytoplasmic concentrations occur during the proliferative phase. There may be two causes for the changes in steroid hormone receptor concentration in the myometrium during the menstrual cycle:

\section{Progesterone, the predominant steroid hormone} during the second half of the cycle, acts as a negative effector both for its own receptor and for the estradiol receptor, reducing the concentration of both during the second half of the cycle, and

2. due to the inductive effect of the progesterone receptor mechanism, there is a large increase in $17 \beta$ hydroxysteroid dehydrogenase activity, which reduces the intracellular estradiol concentration.

The result is that the estradiol receptor mechanism, which is responsible for both its own induction and that of the progesterone receptor, is blocked $(10,29,30)$.

The results of the comparative analysis of steroid hormone receptor levels in normal myometrium and leiomyomas from the same uteri are rather interesting. The present study shows that leiomyomas are characterized by low cytoplasmic concentrations of progesterone receptors, but high estradiol receptor levels, comparable to those in normal myometrium. This observation is supported by the comparison of the sedimentation patterns of nucleus-bound steroid hormone receptors from normal myometrium in the middle proliferative and early secretory phases and from leiomyoma, and by kinetics of steroid hormone transfer from the cytoplasm to the nucleus under equilibrium conditions.

Our results on the estradiol receptor are in agreement with the findings of Farber et al. (31), Puukka et al. (33) and with the most recent data of Daxenbichler et al. (32), who were also unable to find any significant differences in the estradiol receptor complement of leiomyoma and normal myometrium. However, there is a discrepancy with respect to the progesterone receptor content: Daxenbichler et al. found no signifi- cant differences between the two types of tissue, although they report a tendency toward lower progesterone receptor concentrations in the leiomyomas of patients older than 45 years than in normal myometrium from patients of the same age. It is possible that there is a methodological reason for the differences in quantitative results on the progesterone receptors: Daxenbichler et al. used a dextran-coated charcoal procedure with $\left[{ }^{3} \mathrm{H}\right] \mathrm{R} 5020$ as gestagen. This is a high potency, high-affinity synthetic gestagen with a low dissociation constant, while in the present work, the natural $\left[{ }^{3} \mathrm{H}\right]$ progesterone was used with a multiple dialysis technique.

The low progesterone receptor concentrations found here are supported by the observation of Pollow et al. (34) that leiomyomas are characterized by low $17 \beta$ hydroxysteroid dehydrogenase activity, and this enzyme, as studies by Tseng \& Gurpide $(29,30)$ and our group (10) on human endometrium have shown, is subject to the inductive effect of the progesterone receptor mechanism. One can only speculate on the cause and pathophysiological significance of the differences in progesterone receptor contents of normal myometrium and leiomyoma: Since, as animal experiments have shown, the progesterone receptor is induced via the estradiol receptor mechanism, and thus represents an end product of the chain of estradiol action, it can be inferred that an alteration at one of the steps subsequent to the translocation of the estradiol receptor (transcription, processing, translation) leads to the "progesterone receptor defect". Since the progesterone receptor mediates the physiological braking action of progesterone on the biologically active estradiol, which is responsible for proliferation and mitosis activity, the possibility cannot be excluded that the continuous and uninhibited estrogen stimulation is a cofactor supporting the neoplastic transition. It is too early to speak of an etiological factor, however, since correlations do not prove etiology.

\section{References}

1. Jensen, E. V. \& DeSombre, E. R. (1972), Annu. Rév. Biochem. 41, 203-230.

2. Rao, B. R., Wiest, W. G. \& Allen, W. M. (1974), Endocrinology, 95, 1275-1281.

3. Haukkamaa, M. \& Luukkainen, T. (1974), J. Steroid Biochem. 5, 447-452.

4. Bayard, F., Demilano, S., Robel, P. \& Baulieu, E.-E. (1975), C. R. Acad. Sc. Paris, 281, 1341-1344.

5. MacLaughlin, D. T. \& Richardson, G. S. (1976), J. Clin. Endocrinol. Metab. 42, 667-678.

6. Milton, P., Crocker, S. G. \& King, R. J. B. (1974), J. Steroid Biochem. 5, 329.

7. Robertson, D. M., Mester, J., Beilby, J., Steele, S. J. \& Kellie, A. E. (1971), Acta Endocrinol. 68, 534-542.

8. Evans, L. H., Martin, J. D. \& Hähnel, R. (1974), J. Clin. Endocrin ol. Metab. 38, 23-32.

9. Trams, G., Engel, B., Lehman, F. \& Maass, H. (1973), Acta Endocrinol. 72, 351-360.

10. Pollow, K., Schmidt-Gollwitzer, M. \& Nevinny-Stickel, J. (1977), in: Progesterone Receptors in Normal and Neoplastic Tissues, (McGuire, W. L., Raynaud, J.-P. \& Baulieu, E.-E. eds.) Raven Press, New York, 313-338.

11. Noyes, R. W., Hertig, A. T. \& Rock, J. (1950), Fertil. Steril. 1, 3-25.

12. I. J. Davies (1973), In: Molecular Techniques and Approaches in Developmental Biology (Chrispeels, M. J. ed.) J. Wiley and Sons, New York, 39-54.

13.' Scatchard, G. (1949), Ann. N. Y. Acàd. Sci. 51, 660-672.

14. Lowry, O. H., Rosebrough, N. J., Farr, A. L. \& Randall, R. J. (1951), J. Biol. Chem. 193, 265-275.

15. Brush, M. G., Taylor, R. W. \& King, R. J. B. (1967), J. Endocrinol. 39, 599-607. 
16. Hähnel, R. (1971), Steroids, 17, 105-132.

17. Evans, L. H. \& Hähnel, R. (1971), J. Endocrinol. 50, 209-229.

18. Henderson, S. R. \& Schalch, D. S. (1972), Am. J. Obstet. Gynecol. 112, 762-771.

19. Krishnan, A. R., Hingorani, V. \& Laumas, K. R. (1973), Acta Endocrinol. 74, 756-768.

20. Hähnel, R., Twaddle, E. \& Ratajczak (1973), J. Steroid Biochem. 4, 21-31.

21. Kontula, K. (1975), J. Steroid Biochem. 6, 1555-1561.

22. Haukkamaa, M. (1974), J. Steroid Biochem. 5, 73-79.

23. Jänne, O., Kontula, K., Luukkainen, T. \& Vihko, R. (1975), J. Steroid Biochem. 6, 501-509.

24. Verma, U. \& Laumas, K. R. (1973), Biochim. Biophys. Acta, 317, 403-419.

25. Batra, S. (1973), J. Endocrinol. 57, 561-562.

26. Illingworth, D. V., Wood, G. P., Flickinger, G. L. \& Mikhail, G. (1975), J. Clin. Endocrinol. Metab. 40, 1001-1008.

27. Dyer, R. D., Sarto, G. E. \& Colas, A. E. (1976), J. Clin. Endocrinol. Me tab. 43, 1211-1218.
28. Pollow, K., Schmidt-Gollwitzer, M., Boquoi, E. \& Pollow, B. (1977), J. Molecular Medicine, 2, 61-68.

29. Tseng, L. \& Gurpide, E. (1974), Endocrinology, 94, 419423.

30. Tseng, L. \& Gurpide, E. (1975), Endocrinology, 97, 825833.

31. Faber, M., Conrad, S., Heinrichs, W. L. \& Herrmann, W. L. (1972), Obstetr. Gy necol. 40, 479-486.

32. Daxenbichler, G., Grill, H. J., Wiesinger, H., Wittliff, J. L. \& Dapunt, O. (1977), In: Multiplc Molecular Forms of Steroid Hormone Receptors, (Agarwal, M. K. ed.) Elsevier/ North-Holland Biomedical Press, 163-180.

33. Puukka, M. J., Kontula, U. K., Kauppila, A. J. I., Jänne, O. A. \& Vihko, R. K. (1976), Mol. Cell Endocrinol. 6, 35-46.

34. Pollow, K., Sinnecker, G., Boquoi, E. \& Pollow, B. (1978), J. Clin. Chem. Clin. Biochem. 16, 493-502.

Professor Dr. Kunhard Pollow Institut für Molekularbiologic und Biochemie der Freien Universität Berlin Arnimallee 22 1000 Berlin 33 
.

. - 